Fornuften under troens lydighed er umulig at komme udenom, hvis man skal beskæftige sig med denne periode. Det gælder ikke blot for studier i idéhistorie, men lige såvel kultur- og politisk historie.

MFJ skriver spændende og veloplagt $i$ et flydende sprog. Samtidig færdes han ubesværet $i$ et væld af kilder. Han analyserer ikke blot de store ånders værker, men graver sig ned i love og forordninger, forhandlingsprotokoller og breve, litteratur, ligprædikener og akademiske disputationer. Da forfatteren læser latin, går han direkte til kilderne, og bogen er således et stykke reel grundforskning, hvor MFJ også får ryddet op i en række misforståelser begået af ældre historikere. Samtidig med at han kender og bruger sine kilder til fingerspidserne, fortaber han sig aldrig $i$ trivialiteter og har hele tiden sine overordnede mål og teser for øje. Denne brug af en bred vifte af forskellige kilder gør, at han kan afkode og udlægge ikke blot enkelte forskeres værker og resultater, men tillige give indblik $\mathrm{i}$ en tidsånd og en verdensopfattelse, der på alle måder befinder sig århundreder fra vores. Det er vel denne brug af mange forskelligartede kilder og ikke blot analysen af store tænkere, der i sidste ende adskiller idéhistorie som fag fra filosofihistorie.

Peter W. Frederiksen

\section{Sandhed eller metode}

Semikolon; tidsskrift for studier afidébistorie, semiotik, filosofi, årgang 5, nr. 10, 2005

Det seneste nummer af tidsskriftet Semikolon; lover at gå til sagens kerne, og det lyder jo umiddelbart tillokkende. Hoveddelen af nummeret er en temasektion med bud på, hvordan fagene Idéhistorie, Semiotik og Filosofi skal bedrives. Mindre tillokkende bliver det ikke, når man ved læsning af lederen får det indtryk, at temasektionen er blevet til som en stafet, hvor skribenterne tager tråden op fra den foregående artikel, så sektionen til sidst fremstår som en smukt afrundet helhed, ja en harmoni af de dissonerende holdninger, der findes til metodediskussionen på de respektive institutter.

Lederen lover imidlertid ikke så lidt mere end temasektionen holder. Ved læsning af artiklerne får man indtryk af, at redaktionsarbejdet på dette nummer har været minimalt, og det er ikke godt, når man er ambitiøs nok til at lave et temanummer. Idéen er god, temaet er væsentligt, men sektionen fremstår indholdsmæssigt noget ubearbejdet.

Som resultat af det begrænsede redaktionsarbejde fremstår Paw H. Amdisens artikel som en ørkenvandring, hvor Sløk og Skinners tanker om forskelle og ligheder mellem filosofi og idéhistorie er tæt på at forsvinde $\mathrm{i}$ anstrengende indskudte sætninger, parenteser og analogier, der ender i blindgyder. 
Ud over Amdisen er også Mads Peter Sørensen og Peter C. Kjærgaard blevet ladt i stikken af deres redaktør. Meningen var i følge lederen, at de skulle repræsentere hver sit synspunkt på, hvorvidt idéhistorie bedst bedrives som national- eller kosmopolitisk idéhistorie. Helt elementært er artiklerne kedelige, fordi Sørensen og Kjærgaard er rørende enige, men værre er, at det perspektiv de lægger på problematikken er så begrænset, at artiklerne knap nok løfter sig over banaliteter. Redaktionen skyder sig selv $\mathrm{i}$ foden ved at lade artiklerne trykke - hvis synspunkterne skulle være udtryk for en verserende debat, er de for kedelige til at lave et temanummer om.

Frank Beck Lassens artikel er ikke formuleret direkte $\mathrm{i}$ opposition til andres metodesyn, men en præsentation af aspekter af hans ph.d projekt og herved et rimeligt indlæg i sektionen. Lassen formulerer klart, uden at forenkle, at han eksperimenterer med en vej ind $i$ åndshistorien ved at undersøge betydningsglidninger og brugsforandringer, som udvalgte metaforer optræder gennem historien med. Tiden og Lassens arbejde vil vise, om den historiske semantik er en farbar idéhistorisk vej.

Den største konflikt i metodedebatten synes at stå mellem synspunkterne i temasektionens to sidste indlæg, 'pamfletten' Fra blandvark til baindvark og det efterfølgende interview med Dorthe Jørgensen.
Pamflettens tre forfattere gør det eneste rigtige $i$ en tid som denne, hvor de arbejdsløse humanister efter sigende hænger på træerne: De opfinder et behov for et nyt fag, som de formodentligt gerne selv vil varetage undervisningen af. $\mathrm{Og}$ ansøgningen synes da også stilet direkte til de nye eksterne bestyrelser: Faget skal hedde Metoder som virker. Kortere bliver vejen fra tanke til den eftertragtede lønseddel da ikke - særligt når nu Hegel, den gamle tidsrøver, erklæres for outdated.

Dorthe Jørgensen er en del af den idéhistoriske stab, der er pamflettens prygelknabe. Jørgensen mener, der er en modsætning mellem metode og tænkning, mellem videnskabelige og filosofiske fag. Metode er for de videnskabelige fag, tænkningen for de filosofiske, og hun mener følgeligt ikke, at idéhistorikeren skal have en metode, men derimod reflektere over, hvad tænkning er. Hegels undersøgelse af tankens historicitet og åndens historie står som et forbillede for Jørgensen, der sætter lighedstegn mellem metafysik og filosofi, og hun mener i modsætning til pamflettens forfattere, at Hegels tænkning stadig er relevant for $\mathrm{fx}$ en aktualisering af begreber som metafysik og ånd.

Det kunne være interessant at spørge pamflettens forfattere, om ønsket om at oparbejde en pluralistisk metodebevidsthed omfattede undervisning $i$ en metode til aktualiseringen af netop de begreber, og om metoden i så fald hed tænkning? 
Det havde løftet det samlede indtryk, hvis redaktionen havde ulejliget sig med få artiklerne til at medvise nogle af de filosofiske spørgsmål, en metodediskution på fag som filosofi og idéhistorie stiller. Hertil kunne de have fundet inspiration i Rasmus Navntofts Heidegger og humanismen, som de har placeret uden for sektionen. Med udgangspunkt i Heideggers humanismebrev berører artiklen netop spørgsmålet om tænkningens forhold til praksis, som er centralt i konflikten mellem pamfletten og interviewet. Jørgensen mener, $i$ tråd med Hegel, Heidegger og Adorno, at tænkning i sig selv er praksis og vil formodentligt være enig med Heidegger $i$, at forståelsen af tænkning som en spørgende åbenhed over for væren, er en forstålse, der har trange kår $\mathrm{i}$ vores kultur - og i pamfletter, der selv kan være lige så meget blændværk som håndværk.

Gitte Tofterup Hansen

\section{'Vi kan ikke dissekere histo-} riske tekster som om de skulle vare kreperte pungdyr'

Trond Berg Eriksen: Hva er idébistorie. Universitetsforlaget, 2003, 160 sider, no. kr. 149,- og ARR - idébistorisk tidsskrift (Tema: Idéhistoriens egenart) nr. 4, 2004, 135 sider, no. kr. 70,-

Som yngre idéhistoriker er det betryggende at vide, at man i Norge har de samme definitionskvaler med faget som vi kender til herhjemme. Det kan man forvisse sig om ved at læse ARR, Norges idéhistoriske tidsskrift, som i et jubilæumsnummer $i$ anledning af tidsskriftets 15 år på bagen har kastet spørgsmålet om idéhistoriens egenart ud til skandinavisk debat. Nummeret er sammensat af en række bidrag, der alle figurerede ved ARRs jubilæumsseminar den 10. september 2004. Det kan man mærke. Alle teksterne har karakter af lejlighedsbidrag, og det er faktisk behageligt, at der bliver gået til sagen med en vis gelassenheit overfor det evige genstandsspørgsmål, der jo alligevel aldrig finder andet end en halvgod besvarelse. Som Espen Schaanning påpeger i sin velkomsttale, så bliver man måske lidt træt af spørgsmålet med alderen. Ham selv har det 'fulgt som en mare': 'Det var liksom ikke mulig å bli ferdig med det'! At dette virkelig er tilfældet, opdagede undertegnede, da han skulle sætte ARRs nummer, betitlet Idébistoriens egenart, på plads i boghylden. Der stod sgu en svensk antologi med nøjagtig samme titel i forvejen.

Ikke desto mindre. Blandt de mere interessante bidrag er Dorthe Jørgensens 'Lille programskrift - om idéhistories betydning for historikere og andre', om værkbegrebet som centralt for idéhistoriens historiografi. Værkkategorien tillader os at se det vigtige i idéhistorien, nemlig som en gestaltning af historien, der først herefter er i stand til erkendelsesmæssigt at fremtræde meningsfuld. Jørgensen følger her et klassisk hermeneutisk 